\title{
States as providers of public goods \\ how does government size affect environmental quality?
}

\section{Working Paper}

Author(s):

Bernauer, Thomas; Koubi, Vally

Publication date:

2006

Permanent link:

https://doi.org/10.3929/ethz-a-005388989

Rights / license:

In Copyright - Non-Commercial Use Permitted

Originally published in:

CIS working paper 14(2006) 


\section{uni | eth | zürich \\ Center for Comparative and International Studies (CIS) \\ No 14, 2006}

\section{Working Paper}

Published by the Center for Comparative and International Studies (ETH Zurich and University of Zurich)

\section{States as Providers of Public Goods: How}

\section{Does Government Size Affect Environmental}

\section{Quality?}

Thomas Bernauer and Vally Koubi

ETH Zurich 


\title{
States as Providers of Public Goods:
}

\section{How Does Government Size Affect Environmental Quality?}

Thomas Bernauer* and Vally Koubi**

ETH Zurich

\begin{abstract}
Theories explaining government size and its consequences are of two varieties. The first portrays government as a provider of public goods and a corrector of externalities. The second includes theories on bureaucracy and interest groups. One key difference is that an expansion in government size is unambiguously associated with an increase in social welfare only in theories of the former variety. As to the latter variety, the association between government size and public goods provision (or social welfare) is either negative or ambiguous. We study the empirical significance of these competing claims by examining the relationship between government size and environmental quality (notably, air quality measured by $\mathrm{SO}_{2}$ concentrations) for 42 countries over the period 1971-96. We find that the relationship is negative. This result does not prove conclusively that government size expansion has been driven by factors other than concern for the public good. But it supports a presumption against the theory of government size that emphasizes public good provision.
\end{abstract}

Keywords: Government size, public expenditure, public goods, corruption, environmental quality

* Thomas Bernauer is a Professor of Political Science at ETH Zurich. He is based at the Center for Comparative and International Studies (CIS), ETH Zurich, Switzerland; Phone: +41-1-632-6466; Fax: +41-1-632-1289; bernauer@ir.gess.ethz.ch ** Vally Koubi is a Senior Scientist at the Center for Comparative and International Studies (CIS), ETH Zurich, and a Professor in the Department of Economics, University of Bern; koubi@ir.gess.ethz.ch 


\section{Introduction}

Government size around the world grew considerably during the $20^{\text {th }}$ century, with the biggest acceleration occurring around 1960. ${ }^{1}$ Tanzi and Schuknecht (2000) present public spending data for 17 industrialized countries. They report that, while average government size grew by 22 percent between 1937 and 1960, this average grew by 54 percent between 1960 and 1980. Since 1980, public spending has increased much slower, with the average size of government spending in the 17 countries being only 6 percent larger in 1996 than in 1980.

The public choice and political science literature offers several theories of government size. These theories can be classified according to various criteria. A common classification is based on the distinction of demand-side versus supply-side driving forces or, equivalently, on the distinction of citizen-over-state versus state-overcitizen considerations. Citizen-over-state theories rely on the premise that the size of government is demand-driven; thus it reflects the demand for government services (programs) by the citizens as a whole or by subgroups of citizens. The main theories within this category can, in turn, be put into two subcategories: a) the government as a provider of pure public goods and a corrector of externalities (Pigou, 1923); and b) the government as a provider of services to special interest groups (Olson, 1965). ${ }^{2}$

\footnotetext{
${ }^{1}$ Peacock and Wiseman (1961) argue that the growth of government size might be due to the existence of a ratchet effect of wars. That is, once government spending increases due to a war it does not fall back to its original levels. Henrekson (1990) does not find empirical support for this hypothesis.

${ }^{2}$ While a third subcategory is often mentioned, namely the government as an executor of income-wealth redistribution, it seems that this subcategory is not distinct but rather a
} 
State-over-citizen theories emphasize the supply-side determinants of government size and, in particular, the incentives of government bodies to expand their size beyond the level demanded by the citizens. While the main theories in this subcategory are usually divided into yet further subcategories, such as bureaucracy theory (Niskanen, 1971) and the Leviathan theory (Brennan and Buchanan, 1977, 1980), the underlying logic for all these theories and subcategories is similar. Governments as a whole or individual government agencies occupy a monopoly position in the respective society. Hence they are in a position to select the quantity and type of services they provide based mostly on their own preferences and objectives. There are many different ways in which governments can deviate from citizens' preferences in this respect. For instance, they may provide services demanded by the public but at a cost that exceeds the efficient level. Or they may bundle together public services with services that benefit themselves. In all these cases, public goods provision, if it occurs at all, is a side issue.

The above classification suggests that there is only one situation where an expansion in the size of government is likely to be unambiguously welfare improving for society as a whole; namely, when this expansion is demand-driven (citizen-over-state) and when it aims at the provision of a pure public good or the correction of an externality. In all other cases, welfare is either decreasing as the size of government grows, or it is not possible to relate government size to welfare in an unambiguous way. Hence, devising an empirical test that would provide information on the validity of the first theory against

part of one of the previous two. According to liberals, income redistribution belongs to the second, while according to socialists to the first category. 
all of the remaining theories seems important for assessing the welfare implications of government size.

A large body of literature has examined empirically individual components of individual theories. It has, for instance, compared the costs of private and public entities that provide similar services, such as hospitals and water utilities ${ }^{3}$. Remarkably, however, we could not find any studies that attempt to relate empirically the size of government to the provision of public goods. This may in part be due to the fact that there is little agreement on what constitutes a public good. And when there is agreement, it may not be easy to assess whether the public good is provided in an efficient way (as the theory of government as a provider of public goods asserts) or whether it is done in a self-serving way (as the state-over-citizen theories postulate).

In this paper, we evaluate the theory of government as a public goods provider by studying the relationship between government size and the provision of a particular, public good, namely environmental quality. We have chosen environmental quality because it is, by and large, a pure public good. For reasons outlined below, we use sulfur dioxide $\left(\mathrm{SO}_{2}\right)$ as our measure of environmental quality. We examine the relationship between government size and $\mathrm{SO}_{2}$ concentrations in 42 countries over the period 197196, controlling for important economic and political determinants of environmental quality. Our key finding is that this relationship is negative, that is, countries with a larger government size tend to suffer from lower environmental quality.

Several caveats are in order. Finding that the size of government is negatively related to the provision of a particular environmental good (related to $\mathrm{SO}_{2}$ ) does not

\footnotetext{
${ }^{3}$ See Mueller (2003) for a comprehensive summary of the results of such studies.
} 
prove that a similar relationship exists between government size and overall environment quality provision, or between government size and overall public goods provision (and moreover, that this is the case in each and every country in our sample). Regarding the first issue, Bernauer and Koubi (2005) establish that most forms of air pollution (such as $\mathrm{SO}_{2}, \mathrm{CO}_{2}, \mathrm{~N}_{2} \mathrm{O}$ and $\mathrm{NO}_{\mathrm{x}}$ ) behave quite similarly across countries, so $\mathrm{SO}_{2}$ is a reasonably good measure of air pollution in general. Regarding the second issue, one could argue that the only circumstances under which this finding would lack applicability to general public goods provision would be if there were strong substitutability between different types of public goods; a government that ignored environmental degradation could thus be one that placed great emphasis on education or health or defense. This may well be the case and deserves further examination. But while awaiting the results of such studies, one cannot escape the conclusion that our findings do create a presumption against the theory of government as a provider of public goods and corrector of externalities.

The remainder of the paper is organized as follows. Section 1 develops competing theoretical propositions. Section 2 describes the data and the empirical methodology. It also presents the empirical findings. Section 3 concludes.

\section{Theory and Propositions}

\section{Citizen-over-state theories}

The basic premise of the theories under this heading is that the size of government is demand driven. As noted above, the first type of theory in this category assumes that the government provides public goods and corrects externalities according to the demands by the median voter. A large government, in this context, can result from: 
a) Widespread externalities, which in turn could result from the absence of markets or market failure. For instance, it is often argued that the government should provide educational or health services (either directly or indirectly by subsidizing private production) because both the education and health attainment of an individual have positive effects for the society as a whole, and these positive effects are not internalized by individual consumers of such goods.

b) From differences in the elasticity of demand between private and government goods. If government provides mostly services and if manufacturing is done mostly by the private sector, then the relative price of government services will be increasing over time if the source of productivity gains in the economy is primarily the manufacturing sector (as it has always being the case). This is because the supply of manufacturing output will be increasing faster than that of services, which necessitates a price change in favor of services (Baumol, 1967; Mueller, 2003).

c) From a change in preferences over time in favor of public goods and services (Mueller, 2003).

The theory of government as a provider of services to special interest groups originates with Olson (1965). By applying political pressure such groups can obtain desired policies that have beneficial effects for the members of the group at the expense of society as a whole. While the actions of some of these groups may lead to a smaller government size (for instance, when business lobbies achieve lower taxation), empirically the net effect of the various interest groups in most countries seems to have been an increase in government spending. For instance, Sobel (2003) shows that there is a positive relationship between political action committees (PACs) and federal spending in 
the United States. He also shows that this relationship is significant, with a $10 \%$ increase in the number of PACs in any period leading to an increase in US federal spending in the subsequent period by between 1.07 and 1.57 percent.

The activities of government as a redistributor of income and wealth may also be classified under this heading. Redistribution invariably takes the form of higher taxes and spending (transfers), with a direct effect on the government spending to GDP ratio. Moreover, to the extent progressive taxation (the key tool for income redistribution) has adverse effects on economic activity, there is an indirect, positive effect on this ratio through the resulting reduction in GDP.

\section{State-over-citizen theories}

The basic premise of these theories is that the size of government is supply driven. The two main versions, bureaucracy theory and Leviathan theory, emphasize the key role played by the monopoly position of government.

Bureaucracy theory: According to Niskanen (1971) the key objective of government bureaucrats is to maximize the size of their agencies. This does not preclude the possibility that these agencies provide useful public services. Nonetheless, this theory assumes that the size of various public agencies tends to exceed the size that would have obtained if these agencies had simply and passively responded to the median voter demand for public services.

Leviathan theory: The main idea of this theory derives from economic theory, which explains how a (private) monopolist can increase his profit by bundling other products that he does not monopolize with his monopolistic product. Tullock (1959) describes how elected politicians can increase the size of the government by bundling 
together public and various private goods - such as policies that lead to personal financial gains, or to goods provision that increases their probability of reelection. Vote trading plays a crucial role in this process as legislators vote for other legislators’ pet projects in exchange for their votes on their own projects. The "earmarks"4 practice of the United States Congress is a good example (see, e.g., Economist, “Lexington”, January 19, 2006). $\underline{\text { Propositions }}$

Except for interest group theories, citizen-over-state theories claim that government is a provider of pure public goods and a corrector of externalities. Thus public goods provision increases with government size. The state-over-citizen category theories (bureaucracy theory, Leviathan theory) argue that the relationship between government size and public goods provision ranges from ambiguous to negative. Studying the relationship between government size and public good provision may thus generate information that could prove helpful in assessing the validity of these competing theories.

\section{Empirical Analysis}

Our empirical analysis focuses on environmental quality for two reasons. First, environmental quality can, to a large degree, be considered a pure public good. It is true that some components of overall environmental quality may be “impure” public goods, notably in terms of differing access to the good by different parts of society - e.g. poorer people may have to live in areas affected by higher air pollution or water safety problems, or closer to toxic waste dumps or noisy streets or airports. We submit, however, that by

\footnotetext{
${ }^{4}$ Earmarks are spending projects that are directly requested by individual members of Congress and are not subject to competitive bidding.
} 
and large clean air, clean water, biodiversity, and other environmental goods in a country, to the extent they exist, can be enjoyed by most members of that country; we also submit that consumption of such goods by one member of society tends to have only minor, negative effects on the availability of the resource for consumption by other members. The second reason is that environmental quality can be measured at sufficient levels of precision across countries and time to test the aforementioned theoretical claims quantitatively for a relatively large number of countries and years.

We begin by defining our measure of environmental quality and the independent variables to be used in this analysis, and then present the results of the statistical analysis.

\section{Variables}

Environmental quality: air pollution: $\mathbf{S O}_{2}$

Our measure of environmental quality is air pollution, and in particular sulfur dioxide $\left(\mathrm{SO}_{2}\right)$ concentrations. We have chosen $\mathrm{SO}_{2}$ concentrations for several reasons. First, air quality is widely regarded as one of the most important environmental quality indicators (Konisky, 1999). $\mathrm{SO}_{2}$ is one of the so-called criteria pollutants ${ }^{5}$. It is used by the World Bank, the OECD and numerous other national and international authorities to describe air quality.

Second, $\mathrm{SO}_{2}$ is perhaps the most prominent form of air pollution worldwide, since it has direct effects on human health, ecosystems, and the economy.

Third, $\mathrm{SO}_{2}$ emissions can be controlled, if governments wish to, by altering the techniques of production. While some sulfur dioxide is also emitted by natural sources,

\footnotetext{
${ }^{5}$ Carbon monoxide (CO), nitrogen oxide $\left(\mathrm{NO}_{2}\right)$, ozone $\left(\mathrm{O}_{3}\right)$, particulate matter $\left(\mathrm{PM}_{10}\right.$ and $\mathrm{PM}_{2.5}$ ), and lead $\left(\mathrm{P}_{\mathrm{b}}\right)$ are the other criteria pollutants.
} 
such as volcanoes and decaying organic matter, it is primarily produced from the burning of fossil fuels such as oil, coal, and natural gas. In advanced industrialized countries, $\mathrm{SO}_{2}$ is nowadays produced mainly from electricity generation and the smelting of non-ferrous ores, whereas in developing countries and transition economies it is primarily emitted from the burning of diesel fuel and home heating. This implies that $\mathrm{SO}_{2}$ emissions can be curtailed, for example, by reducing consumption of fossil fuels (especially high-sulfur coal), by using smoke-scrubbing equipment in power plants and smokestacks, by reducing the sulfur content of fossil fuels, and by increasing energy efficiency. Although these emission reduction measures are quite costly, many countries around the world and international organizations have established standards and ambient concentration limits in order to protect public health and the environment.

Fourth, availability of data that is commensurable for a large number of countries and over long time periods is a major problem in this type of research. Data for $\mathrm{SO}_{2}$ concentrations is more reliable than data for other forms of air pollution, and it is also available for a rather large number of countries since the 1970s. We chose to focus on ambient data (i.e., $\mathrm{SO}_{2}$ concentrations) rather than emissions. Concentration levels are more likely to influence median voter and government behavior than emissions because they are experienced much more directly in daily life than emissions per se. In addition, concentrations data tends to be more reliable than emissions data. ${ }^{6}$

\footnotetext{
${ }^{6}$ Focusing on emissions, if high quality data were available, would offer opportunities for studying the effects of emissions in one country on emissions (or emission reductions) in other countries. Spatial econometrics has recently started to address this issue. But data for the transportation matrices of air pollutants is not available to the extent that would be
} 
Fifth, as shown by Bernauer and Koubi (2005) $\mathrm{SO}_{2}$ is a meaningful measure of air pollution in general because various important forms of air pollution such as $\mathrm{SO}_{2}, \mathrm{CO}_{2}$, $\mathrm{N}_{2} \mathrm{O}$, and $\mathrm{NO}_{\mathrm{x}}$ behave similarly across countries and time. Some studies include several pollutants (e.g., Grossman and Krueger, 1995; Barrett and Graddy, 2000). However, the problem with this approach is that data for different pollutants is available for different sets of countries and years. This renders comparisons of results across pollutants very difficult.

Our data for sulfur dioxide $\left(\mathrm{SO}_{2}\right)$ concentrations consists of annual observations (averaged over the sites available in any country) for the years 1971-1996 from 42 countries. This data has been collected through standardized procedures in the framework of the Global Environment Monitoring System (GEMS) ${ }^{7}$ - see Appendix for the sources of the data.

Following Antweiler et al. (2001) we use the logarithmic transformation of the median $\mathrm{SO}_{2}$ concentration. The unit of measurement is micrograms per $\mathrm{m}^{3}$. Antweiler et al. (2001) point to a 1984 WHO report on the GEMS/AIR project that argues that concentrations are more suitably described by a log-normal distribution, for the

required for the analysis in this paper - this data is available only for selected OECD countries, with incomplete coverage over time.

${ }^{7}$ The GEMS is sponsored by the World Health Organization (WHO). The US Environmental Protection Agency (EPA) maintains this data in its Aerometric Information Retrieval System (AIRS). 
distribution of concentrations is highly skewed towards zero when viewed on a linear scale. ${ }^{8}$

\section{Government size: Government spending: gov. spend}

Our measure of the size of government is the share of total (nominal) government expenditure in (nominal) GDP. This captures the share of national income that is directly administered by the government. The data for this variable is quite homogeneous across countries and is also readily available. Our data source is the International Financial Statistics data base of the IMF.

Although we are interested primarily in the impact of government size on environmental quality, we need to control for a number of other factors that have been identified in the relevant literature as important determinants of $\mathrm{SO}_{2}$ concentrations. These additional determinants of environmental quality can be grouped in two broad categories, political and economic variables.

\section{$\underline{\text { Political variable }}$}

\footnotetext{
${ }^{8}$ We use national averages (per year) from variable numbers of measurement stations, most of which are located in large cities. The number of measurement stations per country is largely proportional to country size. Aggregation of such concentrations data is, from an atmospheric sciences viewpoint, problematic - for example, air pollution tends to be higher in cities than in the countryside. However, our justification for aggregation is that clean air policies are usually driven by public attention to actual or potential trouble spots, which are largely congruent with the measurement stations in our dataset. Concentration levels at those trouble spot thus provide a reasonably good picture of national policy ambition levels and actual outcomes of overall national clean air policy.
} 


\section{Political System: Democracy}

Many authors (Olson, 1993; McGuire and Olson, 1996; Niskanen, 1997; Lake and Baum, 2001; Bueno de Mesquita et al, 2003; Deacon, 2005) have argued that non-democratic regimes are likely to underprovide public goods, including environmental quality. The logic is as follows. Non-democratic regimes are typically ruled by small elites that use the resources of their respective country to create personal wealth and to redistribute income from their populations towards themselves. If the costs of stricter environmental policies are born disproportionately by the elites (as it would for example be the case with restrictions on polluting industrial activities) while the benefits are uniformly dispersed throughout the population, then these elites would have little incentive to implement such policies. In contrast, in democracies the median voter, who decides on public policy, faces a lower cost from environmental policies relative to the economic and political elite. This makes the adoption and implementation of stricter environmental policies more likely in democratic regimes.

Congelton (1992), however, argues that elected governments may have shorter planning horizons than non-elected governments because of political myopia. For example, many forms of environmental degradation develop slowly and over long periods of time (e.g. climate change, biodiversity, air and water pollution). Consequently, the social costs of current economic behavior and political choices often materialize over the long term and burden future generations and future politicians. Democracies may, as a result, undersupply environmental public goods relative to non-democratic regimes where political leaders do not face frequent (re-) election and can take more costly 
decisions (stricter environmental policies) with longer term benefits without fear of been punished by myopic voters.

Our measure for the political system variable is an index capturing the extent of democratic participation in government, Democracy, from the POLITY IV data set. It is a composite index that includes the following elements: presence of competitive political participation, guarantee of openness and competitiveness of executive recruitment, and existence of institutionalized constraints on the exercise of executive power. It is expressed on an additive eleven-point scale (0-10). With a view to the abovementioned theoretical arguments we expect the sign of the relationship between democratic political systems and environmental quality to be ambiguous.

\section{$\underline{\text { Economic variables }}$}

A large body of theoretical and empirical literature focuses on economic determinants of environmental quality. It has led to the identification of two important empirical patterns (e.g., Grossman and Kruger, 1995; Selden and Song, 1994). First, some forms of environmental degradation, e.g., $\mathrm{SO}_{2}$ air pollution, follow a Kuznets curve pattern. That is, pollution first deteriorates and then improves as income per capita increases. The standard interpretation of this finding is that environmental quality is a luxury good in the initial stages of economic development. Poor countries facing a trade-off between protecting the environment and improving material living standards opt for the latter. Once significant gains have been made in living standards, the opportunity cost of stricter environmental policies becomes (relatively) smaller and voters are prepared to accept lower economic or personal income growth (the two may not be identical) in order to enjoy less pollution (the environment becomes a normal good). 
The second empirical pattern concerns the implications of international trade for the environment. While the sign of this relationship is theoretically ambiguous because of offsetting forces (the pollution haven hypothesis, the positive effects of trade on income, and the effects of trade on the scale of production), Antweiler et al. (2001) find that, at least for $\mathrm{SO}_{2}$, the net effect of trade is to reduce pollution levels.

Almost all studies on the environment-economy relationship use income (GDP) as the measure of economic activity. That is, they employ income as a surrogate for a number of underlying economic factors whose individual influences on environmental quality are difficult to differentiate. In this paper, following Antweiler et al.(2001), we decompose economic activity into scale, composition, and technique effects to account for the different effects that income (and production and economic development) may have on environmental quality. We also include trade.

Scale effect: Intensity of economic activity: activity

The larger the scale of economic activity per unit is, the higher the level of environmental degradation (i.e., pollution) is likely to be. That is, increased economic activity tends to result in more $\mathrm{SO}_{2}$ emissions and thus higher levels of ambient $\mathrm{SO}_{2}$ concentration. We measure the scale of economic activity by GDP per square kilometer. This measure reflects the concentration of economic activity within a given geographical area. It is constructed by multiplying per capita GDP by population density (population / square kilometers) - this, in effect, results in a coefficient measuring GDP per square kilometer. We expect a positive relationship between economic activity and environmental degradation. 


\section{Composition effect: Capital intensity of production: capital}

The composition of economic activity influences environmental quality because different sectors of the economy affect environmental quality differently. For example, industry and especially manufacturing may pollute more than either agriculture or services, depending on the form of pollution. We represent economic structure by a nation's capital to labor ratio and expect a positive effect on pollution.

\section{Technique effect: income}

At lower income levels people tend to be more concerned with food, shelter, and other material needs, and less concerned with environmental quality. They are also less likely to be able to afford costly environmental clean-up measures. At higher income levels people usually demand higher levels of environmental quality, and they can afford higher environmental clean-up costs. We expect a negative effect of per capita income on pollution since increasing economic prosperity leads to stronger public demand for pollution abatement and provides the necessary resources to achieve it. We assume that pollution policy is flexible and responsive to changes in the economy, but that it takes time for income increases to affect policy. Thus, we proxy the 'technique effect' by a moving average of lagged income (a three-year average of lagged GDP per capita).

\section{Degree of trade openness: trade}

Some authors have incorporated international trade in their analysis of economyenvironment linkages (e.g., Frankel and Rose, 2005). They argue that trade affects the domestic economy and therefore also environmental behavior. The sign of this relationship appears theoretically ambiguous because of offsetting forces. Yet, Antweiler et al. (2001) find that, at least for SO2 concentrations, the net effect of trade is to reduce 
pollution levels. In this analysis we measure a country's trade openness by the ratio of the sum of exports and imports to GDP.

Time trend: year

We add a time trend to our regression analysis to capture the general trend towards higher environmental quality observed during the sample period. This trend is probably due to the existence of a trend in income, capital intensity, and intensity of economic activity.

\section{Statistical model}

Combining the variables discussed above, we obtain the following statistical model:

$$
\begin{aligned}
\mathrm{SO}_{2 \mathrm{kt}}= & \beta_{0}+\beta_{1} *\{\text { government size }\}+\beta_{2} *\{\text { political variable }\}+\beta_{2} *\{\text { economic } \\
& \text { variables }\}+\beta_{3} * \text { year }+\mathrm{e}
\end{aligned}
$$

where $\mathrm{SO}_{2}$ is the log of the median of $\mathrm{SO}_{2}$ concentrations in country k (averaged over the sites available in each country and year), at time t. $\beta_{\mathrm{i}}=1,2,3$ are fixed coefficients.

We have applied standard OLS regression analysis to our panel data (42 countries, 1971-1996), with the required correction (due to the cross sectional dimension of the data) for heteroskedasticity. In addition, we have also run robust regressions in order to make sure that our results are not unduly influenced by outliers.

\section{Results}

Table 1 shows the correlation coefficients for the variables used in the analysis.

Insert Table 1 about here 
As shown in Table 1, the correlation coefficient for all pairs of the independent variables are significantly away from unity, which implies that we do not need to be concerned about multi-collinearity.

Table 2 presents the estimated regression without correction for heteroskedasticity.

Insert Table 2 about here

All coefficients for the economic and political variables are statistically significant at the $1 \%$ level and have the expected sign (note that a negative sign indicates a favorable effect on air pollution, as the dependent variable captures the level of pollution). As a matter of fact, the results are very similar to those that have been reported in the literature before. Higher income translates into lower pollution, while a higher scale of economic activity or higher capital intensity (manufacturing) tend to increase pollution. The net effect of international trade is to reduce pollution. Similarly, as has been established by some previous studies and for several types of environmental quality indicators, democracy has a positive effect on environmental quality as well ${ }^{9}$. The time trend is negative, that is, air pollution has declined as a function of time.

The variable of principal interest is government size. The effect of government size on air pollution is negative and quite strong, both statistically and quantitatively. An increase in the share of government spending in GDP by one percentage point is

\footnotetext{
${ }^{9}$ Grossman and Krueger (1993), Barrett and Graddy (2000), Harbaugh et al. (2000), Torras and Boyce (1998).
} 
associated with an increase in $\mathrm{SO}_{2}$ concentrations by 2.33 percentage points. It is worthwhile, thought, to note that this effect is not constant over the range of government sizes observed in the sample. When we add a quadratic term in government size to the list of regressors we find that the coefficient for the linear term remains the same (both in size, sign and statistical significance) and the coefficient for the quadratic term is negative and statistically significant (but quite small in size, indicating the absence of substantial nonlinearities). This means that successive increases in government size, while always detrimental to air quality, have a declining negative impact on air quality. The overall properties of the regression equation are quite good, with an adjusted Rsquare of 0.38 .

Could these results be due to the presence of cross-sectional dependence? Table 3 repeats the analysis, but corrects for heteroskedasticity.

Insert Table 3 about here

The results are virtually identical to those reported in Table 2 .

Could these results be due to the influence of outlier observations? Table 4 reports the estimated coefficients using robust estimation techniques.

Insert Table 4 about here 
The results are not materially affected. The estimated coefficient for government size drops somewhat (from 2.33 to 1.7 ) but it remains quite large, both statistically and quantitatively.

Having established that government size has a negative effect on air quality, at least as far as $\mathrm{SO}_{2}$ concentration is concerned, we now probe somewhat further to understand the possible sources of this association. Could it be, for instance, that it is not government size per se that matters for the provision of environmental quality as a public good, but rather how corrupt a government is? Several authors (e.g., Goel and Nelson, 1998; Scully, 1991) show that corruption tends to increase with government size. Scully (1991:99), for example, argues "the increase in the size and scope of government expenditure represents an enormous rise in the opportunities for rent-seeking through budgetary reallocations.”

Many authors have argued that corruption appears to sap economic growth and to induce socially suboptimal government policies. Mauro (1995) shows that corruption reduces economic growth by lowering the incentives of both domestic and foreign investors to invest, by lowering the quality of public infrastructure and services, decreasing tax revenues, and distorting the composition of government expenditures. Mauro (1996) and Tanzi and Davoodi (1997), based on cross-country comparisons, show that corruption alters the composition of government spending. Specifically, corruption shifts spending away from education, health and maintenance of existing infrastructure and towards public investment such as large public construction works and buildup of the military. 
Corruption seems to contribute to environmental degradation too. According to the authors of the Environmental Sustainability Index (2005) that ranks nations by environmental performance, corruption is one of the most highly correlated (among the 67 quality-of-life variables included in the index) with poor environmental quality. One possible explanation for this relationship might be that in highly corrupt societies, government officials accept bribes in return for not enacting environmental regulations and enforcing environmental laws ${ }^{10}$. Moreover, Fredriksson and Svensson (2003) develop a model to study the interaction effects of corruption and political stability on environmental policy. They find that while corruption reduces the stringency of environmental regulation (they use an index for the agricultural sector alone) its effect disappears as political instability increases. Lopez and Mitra (2000) develop a formal model to investigate the effects of corruption on the relationship between income and pollution levels and establish that for any level of per capita income, corruption leads to pollution levels that are always above the socially optimal.

We have thus included a measure of corruption in the regression along side the government size variable. We use a corruption index (corruption) that has been developed by the International Country Risk Guide. This index has been extensively used in previous work. It ranges from 0 to 6 , with 6 indicating low corruption and 0 indicating high corruption levels. Lower scores indicate that high government officials are likely to demand special payments, and that illegal payments are generally expected throughout lower levels of government in the form of bribes connected with services such as import

${ }^{10}$ Desai (1998) shows that corruption contributes significantly to environmental degradation in developing countries. 
and export licenses, tax assessments, etc. We expect that high levels of corruption lead to higher levels of $\mathrm{SO}_{2}$ concentrations.

Table 5 reports the results from robust regression analysis.

Insert Table 5 about here

Table 5 shows that the inclusion of this variable does not change the results materially. The estimated coefficient for the corruption variable is negative (the "cleaner" the government, the smaller the pollution) and statistically significant at the $1 \%$ confidence interval. Nonetheless, the estimated impact of government size on air quality remains unfavorable. It is even larger now that we have accounted for differences in levels of corruption across countries. This result suggests that there are additional channels (besides the government size $=>$ corruption $=>$ low public goods provision channel) through which a large government may have harmful consequences for the environment. The one that has been emphasized in the literature is special interest groups that support a large government in order to derive private benefits. If the dominant special interest groups are not promoters of environmental quality, then such an association can obtain. The finding of Bernauer and Koubi (2005) that labor union strength is negatively associated with air pollution is consistent with this interpretation.

\section{Conclusions}

Several theories have sought to explain the size of government and its consequences for public goods provision and social welfare more generally. These theories have very 
different implications regarding the welfare effects of government activity. If government exists exclusively in order to provide pure public goods and correct externalities, then bigger government size implies a higher level of welfare. If governments' key function is, to varying but substantial degrees, to serve the interests of individual groups at the expense of other groups then the effect of bigger government on social welfare is either negative or ambiguous.

These competing theories are difficult to test empirically because of controversies associated with the identification of pure public goods as well as optimal levels of their provision. In this paper we have made a first attempt to evaluate the empirical relevance and significance of the theory that assumes governments to act primarily as pure public goods providers and correctors of externalities. We do so by examining the relationship between government size and the provision of environmental quality. The environmental good examined is air quality. We have found that the relationship is negative and quantitatively significant. More government spending as a percentage of GDP goes hand in hand with more air pollution.

We have argued that this finding does not prove conclusively that government size expansion has been driven by concerns other than public goods provision. First, environmental quality is but one of the many public goods that may be provided by governments. Second, $\mathrm{SO}_{2}$ pollution is but one form of air pollution, albeit an important one that tends to reflect general air pollution levels. Third, we do not have a concrete, empirically testable theory of the optimal level of pollution. Fourth, we need more refined theoretical arguments on and empirical tests of how government size, democracy, corruption, and rent-seeking by special interest groups interact in influencing public 
goods provision. One hypothesis to be investigated further is that large government size in autocracies leads to low levels of public goods provision primarily through corruption, whereas in democracies it does so primarily through rent-seeking. Nonetheless, our finding creates a prima facie presumption against the theory of government size that emphasizes benevolent public goods provision. In any event, more work examining the relationship between government size and other environmental goods is needed in order to establish the generality of our results. 


\section{References}

Antweiler, Werner, Brian R. Copeland, and M. Scott Taylor. 2001. "Is Free Trade Good for the Environment?” American Economic Review 91 (4): 877-908.

Barrett, Scott, and Kathryn Graddy. 2000. "Freedom, Growth, and the Environment,” Environment and Development Economics 5 (4): 433-456.

Baumol, William J. (1967) “The Macroeconomics of Unbalanced Growth: The Anatomy of Urban Crisis,” American Economic Review 57(3): 415-426.

Bernauer, Thomas and Vally Koubi (2005) "Political Determinants of Environmental Quality,” Mimeo. Center for Comparative and International Studies (CIS), ETH Zurich, Switzerland. Available at: http://ssrn.com/author=328076

Brennan, Geoffrey and Buchanan, James M. (1980) The Power to Tax: Analytical Foundations of a Fiscal Constitution. Cambridge: Cambridge University Press.

Brennan, Geoffrey and Buchanan, James M. (1977) “Towards a Tax Constitution for Leviathan,” Journal of Public Economics 8(3): 255-73.

Bueno de Mesquita, Bruce, Alastair Smith, Randolph M. Siverson, and James D. Morrow (2003) The Logic of Political Survival. Cambridge, MA: The MIT Press.

Congleton, Roger D. (1992) “Political Institutions and Pollution Control,” Review of Economics and Statistics 74(3): 412-421.

Deacon, Robert T. (2005) “Dictatorship, Democracy and the Provision of Public Goods,” Mimeo, Department of Economics, University of California, Santa Barbara.

Desai, Uday (1998) “Environment, Economic Growth and Government in Developing Countries,” in U. Desai (ed) Ecological Policy and Politics in Developing Countries: Growth, Democracy and Environment. Albany, NY: State University 
of New York Press.

Environmental Sustainability Index (2005)

http://sedac.ciesin.columbia.edu/edu/es/esi/ESI2005.pdf

Frankel, Jeffrey A. and Andrew K. Rose (2005) "Is Trade Good or Bad for the Environment? Sorting Out the Causality,” Review of Economics and Statistics 87(1): 85-91.

Fredriksson, Per G., and Jacob Svensson (2003) “Political Instability, Corruption and Policy Formation: the Case of Environmental Policy,” Journal of Public Economics 87: 1383-1405 .

Goel, Rajeev K. and Michael A. Nelson (1998) “Corruption and Government Size: A Disaggregated Analysis,” Public Choice 97: 107-120.

Grossman, Gene M, and Alan B. Krueger (1995) “Economic Growth and the Environment,” Quarterly Journal of Economics 110: 53-377.

Harbaugh, William, Arik Levinson, and David Wilson. 2000. "Reexamining the Empirical Evidence for an Environmental Kuznets Curve,” Working Paper 7711, National Bureau of Economic Research, Cambridge, Massachussetts. Henrekson, Magnus (1990) “The Peacock and Wiseman Displacement Effect,” European Journal of Political Economy 6(2): 245-260.

Konisky, David M. (1999) “Comparative Risk Projects: A Methodology for CrossProject Analysis of Human Health Risk Rankings,” Discussion Paper 99-46, Resources for the Future.

Lake, David, and Matthew Baum (2001) “The Invisible Hand of Democracy: Political Control and the Provision of Public Service,” Comparative Political Studies 
34(6): 587-621.

Lopez, Ramon and Siddhartha Mitra (2000) “Corruption, Pollution and the Kuznets Environment Curve,” Journal of Environmental Economics and Management 40(2): 137-150.

McGuire, Martin, and Mancur Olson (1996) “The Economics of Autocracy and Majority Rule: The Invisible Hand and the Use of Force,” Journal of Economic Literature 34(1): 72-96.

Mauro, Paolo (1996) “The Effects of Corruption on Growth, Investment, and Government Expenditure,” IMF Working Paper 96/98. Washington D.C.: International Monetary Fund.

Mauro, Paolo (1995) “Corruption and Growth,” Quarterly Journal of Economics 110(3): 681-712.

Mueller, Dennis C. (2003) Public Choice III. Cambridge: Cambridge University Press. Niskanen, William (1997) “Autocratic, Democratic and Optimal Government,” Economic Inquiry 35(3): 464-479.

Niskanen, William (1971) Bureaucracy and Representative Government. Chicago: Aldine-Atherton.

Olson, Mancur (1993) “Dictatorship, Democracy and Development,” American Political Science Review 87 (3): 567-576.

Olson, Mancur. 1965 The Logic of Collective Action. Cambridge: Harvard University Press.

Peacock, Alan T. and Jack Wiseman (1961) The Growth of Public Expenditure in the United Kingdom. Princeton, NJ: Princeton University Press. 
Pigou, Arthur (1932) The Economics of Welfare. London: Macmillan

Tanzi, Vito and Ludger Schuknecht (2000) Public Spending in the $20^{\text {th }}$ Century. Cambridge: Cambridge University Press.

Tanzi, Vito, and Hamid Davoodi (1997) “Corruption, Public Investment and Growth,” IMF Working Paper 97/139. Washington D.C., International Monetary Fund.

Torras, Mariano, and James K. Boyce. 1998. "Income, Inequality, and Pollution: A Reassessment of the Environmental Kuznets Curve,” Ecological Economics 25 (2): $147-160$.

Tullock, Gordon (1959) “Problems of Majority Voting,” Journal of Political Economy 67(6): 571-579.

Scully, Gerald W. (1991) “Rent-seeking in US Government Budgets, 1900-88,” Public Choice 70: 99-106.

Selden, T.M. and D. Song (1994) "Environmental Quality and Development: Is there a Kuznets Curve for Air Pollution Emissions?” Journal of Environmental Economics and Management 27: 147-162.

Sobel, Russell S. (2001) “The Budget Surplus: A Public Choice Explanation.” Working Paper 2001-05, West Virginia University.

World Health Organization (1984) Urban Air Pollution: 1973-1980. Published under the joint sponsorship of United Nations Environment Program and the World Health Organization. Geneva, Switzerland. 
Table 1: Correlations

\begin{tabular}{|l|r|r|r|r|r|r|r|}
\hline & SO2 & incomedemocracy & capital & activity & tradegov.spend \\
\hline SO2 & 1 & & & & & & \\
\hline income & -0.1877 & 1 & & & & & \\
\hline democracy & -0.1171 & 0.6261 & 1 & & & & \\
\hline capital & 0.086 & 0.4987 & 0.5039 & 1 & & & \\
\hline activity & 0.2944 & 0.3696 & 0.2692 & 0.1691 & 1 & & \\
\hline trade & -0.0971 & -0.0353 & 0.1999 & 0.1163 & -0.2459 & 1 & \\
\hline gov. spend & -0.0285 & 0.0884 & 0.2551 & 0.2235 & -0.266 & 0.6713 & 1 \\
\hline year & -0.3356 & 0.1656 & -0.0341 & 0.0875 & 0.067 & -0.0598 & 0.0648 \\
\hline
\end{tabular}

Table 2: Determinants of SO2 concentrations

\begin{tabular}{|l|r|r|r|r|}
\hline SO2 & Coeff & Std.Err & $\mathrm{t}$ & $\mathrm{P}>|\mathrm{t}|$ \\
\hline income & -0.20 & 0.03 & -6.05 & 0.000 \\
\hline democracy & -0.05 & 0.01 & -4.07 & 0.000 \\
\hline capital & 0.08 & 0.01 & 5.9 & 0.000 \\
\hline activity & 0.06 & 0.01 & 10.89 & 0.000 \\
\hline trade & -0.59 & 0.17 & -3.4 & 0.001 \\
\hline gov. spend & $\mathbf{2 . 3 3}$ & $\mathbf{0 . 4 7}$ & $\mathbf{4 . 9 1}$ & $\mathbf{0 . 0 0 0}$ \\
\hline year & -0.06 & 0.01 & -9.3 & 0.000 \\
\hline cons & 116.80 & 13.10 & 8.92 & 0.000 \\
\hline
\end{tabular}

Number of obs $=421$

Adj R-squared $=0.3793$

$\mathrm{F}(7,413)=37.66$

Prob $>\mathrm{F}=0.0000$ 
Table 3: Determinants of SO2 concentrations, corrected for heteroskedasticity

Corrected for heteroskedasticity

Regression with robust standard errors

\begin{tabular}{|l|r|r|r|r|}
\hline SO2 & Coeff & Std.Err & $\mathrm{t}$ & $\mathrm{P}>|\mathrm{t}|$ \\
\hline income & -0.20 & 0.02 & -8.45 & 0.000 \\
\hline democracy & -0.05 & 0.01 & -3.63 & 0.000 \\
\hline capital & 0.08 & 0.01 & 7.08 & 0.000 \\
\hline activity & 0.06 & 0.01 & 11.39 & 0.000 \\
\hline trade & -0.59 & 0.17 & -3.49 & 0.001 \\
\hline gov. spend & $\mathbf{2 . 3 3}$ & $\mathbf{0 . 4 6}$ & $\mathbf{5 . 0 2}$ & $\mathbf{0 . 0 0 0}$ \\
\hline year & -0.06 & 0.01 & -8.62 & 0.000 \\
\hline cons & 116.80 & 14.14 & 8.26 & 0.000 \\
\hline
\end{tabular}

Number of obs $=421$

R-squared $=0.3896$

$\mathrm{F}(7,413)=53.88$

Prob $>F=0.000$

Table 4: Determinants of SO2 concentrations, taking into account outliers

Taking into account outliers

Robust regression estimates

\begin{tabular}{|l|r|r|r|r|}
\hline SO2 & Coeff & Std.Err & $\mathrm{t}$ & $\mathrm{P}>|\mathrm{t}|$ \\
\hline income & -0.20 & 0.03 & -7.55 & 0.000 \\
\hline democracy & -0.08 & 0.01 & -8.13 & 0.000 \\
\hline capital & 0.06 & 0.01 & 6.42 & 0.000 \\
\hline activity & 0.06 & 0.00 & 13.55 & 0.000 \\
\hline trade & -0.21 & 0.14 & -1.53 & 0.127 \\
\hline gov. spend & $\mathbf{1 . 7 0}$ & $\mathbf{0 . 3 7}$ & $\mathbf{4 . 6}$ & $\mathbf{0 . 0 0 0}$ \\
\hline year & -0.05 & 0.01 & -9.03 & 0.000 \\
\hline cons & 87.47 & 10.21 & 8.57 & 0.000 \\
\hline
\end{tabular}

Number of obs $=421$

$\mathrm{F}(7,413)=56.50$

Prob $>F=0.0000$ 
Table 5: Determinants of SO2 concentrations, adding corruption

Robust regression estimates

\begin{tabular}{|l|r|r|r|r|}
\hline SO2 & Coef. & Std. Err. & $\mathrm{t}$ & $\mathrm{P}>|\mathrm{t}|$ \\
\hline income & -0.16 & 0.04 & -4.1 & 0.000 \\
\hline democracy & -0.06 & 0.01 & -4.31 & 0.000 \\
\hline capital & 0.10 & 0.02 & 5.43 & 0.000 \\
\hline activity & 0.06 & 0.01 & 11.58 & 0.000 \\
\hline trade & -0.36 & 0.16 & -2.25 & 0.026 \\
\hline gov.spend & $\mathbf{2 . 8 8}$ & $\mathbf{0 . 5 1}$ & 5.65 & 0.000 \\
\hline corrupt & -0.18 & 0.05 & -4.07 & 0.000 \\
\hline year & -0.06 & 0.01 & -4.57 & 0.000 \\
\hline cons & 108.23 & 24.73 & 4.38 & 0.000 \\
\hline
\end{tabular}

Number of obs $=205$

$\mathrm{F}(8,196)=29.51$

Prob $>\mathrm{F}=0.0000$ 


\section{Appendix}

\section{A.1: Countries in the sample}

Argentina
Australia
Austria
Belgium
Brazil
Canada
Chile
China
Colombia
Czechoslovakia
Denmark
Egypt
Finland
France
Germany
Ghana
Great Britain
Greece
India
Indonesia
Iran
Iraq
Ireland
Israel
Italy
Japan
Kenya
Malaysia
Netherlands
New Zealand
Pakistan
Peru
Philippines
Poland
Portugal
South Korea
Spain
Sweden
Switzerland
Thailand
United States
Venezuela




\section{A.2: Description of variables and data sources}

The data set was constructed with data taken from the following sources:

$\mathrm{SO}_{2}$ concentrations: $\log$ of the median of $\mathrm{SO}_{2}$ concentrations at site $\mathrm{j}$, city i, in country $\mathrm{k}$, at time t; average from all sites for each country and year. GEMS/AIR, US Environmental Protection Agency (US EPA) (http://www.epa.gov/airs/aexec.html)

Government Size: total nominal government spending divided by nominal GDP. International Monetary Fund, International Financial Statistics

Democracy: Democracy index ranging from 0 to 10 . Polity $I V$ (http://www.cidcm.umd.edu/inscr/polity)

Income: three-year average of lagged GDP per capita. The Penn World Tables, NBER (ftp://ftp.nber.org/pwt56/), and International Monetary Fund, International Financial Statistics

Activity: real GDP/ $/ \mathrm{km}^{2}$ (GDP/population x population $/ \mathrm{km}^{2}$ ). The Penn World Tables

Capital: capital to labor ratio (the amount of the physical capital per worker). The Penn World Tables

Trade: ratio of the sum of exports and imports to GDP. The Penn World Tables

Population: Global Population Distribution Database, The Consortium for International Earth Science Information Network (CIESIN) (http://grid2.cr.usgs.gov/globalpop/1-degree/description.html)

Corruption: corruption index ranging from 0 to 6 , with 6 indicating low and 0 indicating high levels of corruption. International Country Risk Guide (http://www.icrgonline.com/) 